\title{
PUBLIC RELATIONS VS. ADVERTISING
}

\author{
TENGKU ADRIAN ISMAIL \\ JAMILAH HAJI AHMAD \\ UnIVERSITI SAINS MALAYSIA
}

\begin{abstract}
This study aims to examine and understand the effectiveness and credibility of advertising and public relations in the form of editorial coverage. This study involves three main groups, namely prominent practitioners in public relations and advertising as well as independent party who does not belong to either of these categories of practitioners. Guided by the Source Credibility Theory, this exploratory study emphasises on key measure of credibility in finding the overall effectiveness of public relations over advertising. Findings of this study provide ground for constructive argument on the co-relations, effectiveness, estrangement and togetherness of the much debated topic of public relations versus advertising. The main basis of the comparison is based on credibility, and the data focused on three central themes: contribution to brand knowledge and brand image, adequacy of public relations and advertising, and concerns of public relations and advertising practitioners. In short, both public relations and advertising can employ contextual strategy by working together to reach consumers in the most creative and tactical manner.
\end{abstract}

Keywords: Public relations, advertising, credibility, communication and effectiveness 


\title{
PERHUBUNGAN AWAM VS PENGIKLANAN
}

\begin{abstract}
Abstrak
Kajian ini bertujuan untuk mengkaji dan memahami keberkesanan dan kredibiliti pengiklanan dan perhubungan awam dalam editorial. Kajian ini melibatkan tiga kumpulan utama iaitu pengamal bidang perhubungan awam dan pengiklanan serta pihak yang bebas iaitu bukan tergolong dalam bidang perhubungan awam atau pengiklanan. Berpandukan Teori Source Credibility, kajian ini menekankan cara terbaik untuk mengukur keberkesanan praktis perhubungan awam dan pengiklanan. Hasil kajian ini memberi alasan untuk hujah yang membina mengenai hubungan bersama, keberkesanan, kerenggangan dan kebersamaan topik banyak dibahaskan perhubungan awam berbanding pengiklanan. Perbandingan untuk kedua-dua bidang ini adalah berdasarkan kredibiliti dan data yang memberi tumpuan kepada tiga tema utama iaitu: sumbangan kepada pengetahuan jenama dan imej jenama, kesesuaian dalam kedua-dua bidang, dan keprihatinan pengamal perhubungan awam dan pengiklanan. Kesimpulannya, kedua-dua bidang ini boleh bekerjasama dengan menggunakan pendekatan yang kreatif untuk mencapai pengguna.
\end{abstract}

Kata kunci: Perhubungan awam, pengiklanan, kredibiliti, komunikasi dan keberkesanan.

\section{INTRODUCTION}

Public Relations and Advertising are two of the most popular and common communications activities undertaken by companies, organisations, bodies or even countries to convey the messages or tell stories to achieve the desired objectives or intentions. While public relations involves the creation and maintenance of a positive image which is aimed at providing constant and consistent communication with the stakeholders, advertising has an ultimate objective to create sales by informing consumers about the company's products or services in the media.

Building good relationships with strategic publics will need public relations practitioners to be strategic communication managers rather than communication technicians (Grunig, 1992). Advertising, on the other hand, is a non-personal communication of information usually paid for and usually persuasive in nature about products, services or ideas by identifying sponsors through various media (Bovee \& Arens, 1992). 
This study is driven by continuous debate on public relations being more effective and superior compared to advertising, especially in terms of credibility. Questions like what is the impact of public relations in comparison to advertising, and whether the former has greater impact than the latter, or if they are the same; remain the most debatable among practitioners of these two fields. The comparative effectiveness of one over another has long been controversial and despite various studies being conducted to investigate the effect of public relations versus advertising, there is no concrete finding to establish. There is a claim, however, indicating that public relations, media placement, such as editorial coverage (publicity) has a relative value advantage over advertising mainly because of source credibility (Michaelson \& Stacks, 2007). In light of the Source Credibility Theory, this exploratory study aims to examine the effectiveness of public relations (in the form of publicity) in comparison to advertising in Malaysia.

\section{ADVERTISING IN MALAYSIA}

In Malaysia, advertising practices are governed by The Advertising Standards Authority (ASA) which was established in 1977 to provide independent scrutiny of the then newly created self-regulatory system set up by the industry. ASA is an independent body that is responsible to ensure that the self-regulatory system works in the public interest. ASA promotes and enforces high ethical standards in advertisements. The constituent members of ASA as reported at the UNICEF official website are The Malaysian Advertisers Association, Association of Accredited Advertising Agents of Malaysia, Malaysian Newspaper Publishers Association and Media Specialists Association (http:// unicef.org/Malaysia). This is because, if they do, it is to the detriment of advertising as a whole as it compromises its credibility and is inequitable to the companies and practitioners. The companies and practitioners conscientiously verify their claims or refrain from causing offense as a means of merely attracting attention.

ASA administers The Malaysian Code of Advertising Practice that regulates advertising activities in Malaysia. The Code was drawn up by organizations representing advertisers, advertising agencies and media.

The Malaysian Code of Advertising Practice states that, all advertisements should be legal, decent, honest and truthful. They must project the Malaysian culture and identity, reflect the multi-racial character of the population and advocate the philosophy of "RUKUN NEGARA" which reads: Believe in God; Loyalty to the King and the Country; Upholding the Constitution Rule of Law; and Good Behaviour and Morality.

In addition to the Code which stated on the AAAA Malaysia website, there is the Association of Accredited Advertising Agents of Malaysia (the 4As) that is founded in the 1960s, which oversees different aspects of advertising in the country as well as the agents that promote and execute the plans (http:// www.aaaa.org.my). It takes up the role of the mediator between the advertising 
industry and other industries to ensure the quality of its products and services.

In Malaysia, Nielsen Malaysia produces the Malaysia Advertising Expenditure (ADEX) Report that provides a general outlook of the market and the happenings in the industry. It is one way to measure the effectiveness of advertising and the success of any campaign and to report the general outlook of the advertising industry of a certain market (Asia Media, 2014).

Over the last two decades, advertising expenditure (Adex) in Malaysia recorded a steady growth, rising from about RM0.5 billion in 1988 to approximately RM11.2 billion in 2012, with a compound annual growth rate (CAGR) of about $13.8 \%$ between 1988 and 2012. At present, the Malaysian advertising market is considered as one of the most dynamic sectors in the country. A poll conducted by Advertising. my showed that more than half of advertisers are keen on venturing into new media. However, prweb.com reported more advertisers and business owners today are looking for more innovative ways and methods to expand their reach and strengthen their brand image including through new media like LED signboards and social media marketing.

\begin{tabular}{|c|c|c|c|}
\hline \multicolumn{4}{|c|}{$\begin{array}{l}\text { Ad spending for vear-to-date } \\
\text { (VTD) August }\end{array}$} \\
\hline \multirow[b]{2}{*}{ Media type } & \multicolumn{2}{|c|}{ Share (\%) } & \multirow{2}{*}{$\begin{array}{l}\text { Growth vs } \\
\text { YTD Aug } \\
2011(\%)\end{array}$} \\
\hline & $\begin{array}{l}\text { YTD August } \\
2012\end{array}$ & $\begin{array}{l}\text { YTD August } \\
2011\end{array}$ & \\
\hline FTA television & 27.5 & 28.5 & -1.4 \\
\hline Pay television & 24 & 21.8 & 12.6 \\
\hline Newspapers & 40.3 & 41.7 & -1.1 \\
\hline Magazines & 1.3 & 1.3 & 1.4 \\
\hline Radio & 4 & 4.1 & 0.3 \\
\hline Cinema & 0.3 & 0.2 & 71.8 \\
\hline Outdoor & 1.3 & 1.1 & 23.5 \\
\hline In-store media & 1.3 & 1.3 & 2.3 \\
\hline Total & $\begin{array}{r}100 \\
\text { (RM7.1bil) }\end{array}$ & $\begin{array}{r}100 \\
\text { (RM6.9bil) }\end{array}$ & 2.3 \\
\hline
\end{tabular}

Figure1: Advertisement spending in Malaysia up to August 2012 (The star, 2012). 


\section{PUBLIC RELATIONS IN MALAYSIA}

The development of public relations in Malaysia can be divided into three stages which are: public relations before independence, public relations after independence and public relations in the new era. Its development during the last 40 years must be seen within the context of the nation's metamorphoses, through historical era which marks yet another step in the development of the profession (Idid, 2004). According to Idid (2004), Malaysia is one of the countries that has a strong public relations practice.

Public Relations before independence of Malaya goes back to 1926 when the Information Agency of the Malay States was formed to carry out public relations functions of the Government. On 1 April 1946, the Department of Public Relations was established, and in 1950, it was renamed the Department of Information in line with the reorganisation and expansion of duties and responsibilities. Its objective was to restore the image of the British Government after the Japanese occupation in Malaya to bring back the people's trust and confidence in the British. The Department was also tasked to provide information so as to calm and control any negative situation arising from the rise of nationalistic organisations and political parties. It also aimed at removing communication barriers with the people and at the same time gathering and evaluating public opinion.

Post-independence, public relations functions changed from 'inform' - a oneway communication, to 'obtain'- a two-way communication. The new role for public relations practitioners of the Department of Information was to obtain people's support and participation to implement government programmes. The Department was also responsible to instill the spirit of harmony and unity between races through various campaigns.

In 1961, the Department of Information was placed under the Ministry of Information and Broadcasting. It sat in the Prime Minister's Department and under the purview of the then first Prime Minister of Malaysia. At this time, public relations played a vital role in disseminating the right information especially during the confrontation with Indonesia in 1962 and 1963, as well as during the 13 May 1969 racial tragedy.

In 1982, the Public Service Department outlined twelve specific duties for public relations (Mohd Hamdan, 2010). The Information Officers were the pioneers of public relations in the country. Prior to this, the Government appointed press liaison officers for the ministries and press secretaries for the office of the Prime Minister and Deputy Prime Minister. This witnessed the entry of more academically qualified and trained public relations practitioners in the industry.

With multinational companies such as Dunlop, Esso, Lever Brothers, Malayan Tobacco and Shell being among the first companies in the private sector to establish public relations units and use the services of public relations consultancies, its roles became more crucial especially with regard to implementing corporate strategies. 
Public relations further progressed in the 1980s with the Malaysian Government's privatisation policy by the then fourth Prime Minister of Malaysia, Tun Dr Mahathir Mohamad. By 1991, public relations has been widely practiced in private sectors with the launch of Vision 2020 by Tun Dr Mahathir, a forward looking vision to bring Malaysia to become a developed nation in 2020. In achieving this objective, the Government believed that the ideas and philosophy of Vision 2020 should be effectively communicated to people. For this purpose, the Department of Information maximize the use of public relations, including by using the Internet as the new media channel to disseminate information.

Realizing the importance of public relations, huge organizations, including Telekom Malaysia, POs Malaysia and Tenaga Nasional started to use public relations as a tool to build and maintain relationships with their public (Id id, 2004). The larger an organisation is, the greater is the need for the organisation to employ public relations or to set up its own public relations department (Idid, 2004).

While Public Relations are today considered a profession, which, as a matter of fact, plays even an important function in an organization; the debate on whether public relations is a 'true' profession continues to persist. Although public relations scholars acknowledge the importance of professionalism in public relations (Grunig \& Hunt, 1984; Sallot et al., 1997 \& 1998; Cameron et al., 1994; Stacks et al., 1999; L'Etang \& Pieczka, 1996, L'Etang, 1999, 2003 \& 2004; White \& Mazur, 1995), public relations is still seen as a common occupation for a number of reasons.

More often than not, public relations are perceived only as media relations, in which the main tasks are managing press conferences and writing press releases. Some regard public relations as a persuasive tool for marketing (Kotler $\&$ Mindak, 1978; Kitchen, 1997) by which organisations use it as a promotional mix or publicity to achieve marketing goals. Others consider public relations to manage reputations or for image building (Hutton, 1999; Hutton et al., 2001).

Advertising, there are professional associations for Public Relations in Malaysia. According to Abdullah and Threadgold (2007), an independent professional association for public relations is vital, provided that it follows global standards in terms of several key elements of the professional project: strategic plans; universal accreditation (registration); global benchmarking standards; international relations; continuous professional development; a code of ethics; membership benefits; and training and qualification.

The Institute of Public Relations Malaysia (IPRM) was set up in 1962 to promote systematic, organised growth and development of public relations as a profession which can contribute positively to the nation's continuous growth and development in all scopes of human activities. Apart from IPRM, the Public Relations Consultants' Association of Malaysia (PRCA) founded in 1999, to serve as a forum for public relations consultants to discuss industry-related issues, such as quality, professional development, evaluation and training. Its members 
consist of the Public Relations Consultants and Public Relations Consultancies practicing in Malaysia.

The main purpose of this study is to provide an answer to the question, whether public relations and advertising perform differently in terms of credibility of message, as well as brand knowledge, brand image and attributes, as well as brand purchase intent or interest. In addition, it attempts to find a solution to the unresolved debate regarding the effectiveness of these two communication tools and the small amount of empirical data regarding the effect, particularly in the Malaysian context, with the source credibility theory as the base in finding the cognitive behaviour as a result of source credibility and reliability and trustworthiness. This study, therefore has three specific objectives: (1) to examine the co-relations of public relations and advertising in conveying messages that are perceived as credible by the target audience; (2) to compare the communications effectiveness of public relations and advertising; and (3) to suggest if public relations and advertising do come together for the most efficient communications programme.

\section{RESEARCH METHODS}

In order to explore the perspectives of public relations and advertising practitioners pertaining to the value and effectiveness of each tool, a qualitative method (indepth, open-ended interviews) is used to gain a critical and comprehensive view of the subject. The three target groups for this study are public relations practitioners, advertising practitioners, and a neutral party consisting of chief operating officer, media chief editors and art director who have direct or indirect influence over public relations and advertising practices.

While most scientific inquiries focused on quantitative measurement in educational and sociological research, a growing number of studies are conducted using a qualitative research methodology (Krathwohl, 1998; Patton, 1990; Kirk \& Miller, 1986).

Michael Quinn Patton (1990), in his book, Qualitative Evaluation and Research Methods, explained that "Research, like diplomacy, is the art of the possible" ( $p$. 13). Patton notes one of the main values of qualitative methodology is that, it permits the evaluator to study specific issues in depth and to seek greater detail. Yukl (1989) warns that quantitative research can overlook important details that lie outside the rigid, structured boundaries of a study, and thereby become superficial.

Qualitative method was also chosen for this study because it is often the best way - and often the only way - to get data on a subject (Glaser and Strauss, 1967). Krathwohl (1998) explains that qualitative research methods are particularly useful in a number of specific types of studies, including those that aid in: understanding how individuals understand their world, showing how individuals' perceptions in certain situations determine their behavior, exploring phenomena to explain them, and providing detailed descriptions of phenomena. 
On the validity and reliability of data, it has been explained that: "The main thrust of methodological development in qualitative research during the last century has been toward greater validity" (Kirk \& Miller, 1986, p. 42). Many scholars agree that qualitative research can be reliable and valid (Kirk\& Miller, 1986; Patton, 1990; Seidman, 1998; Silverman, 1985).

The Table below lists a summary of the interviews that were conducted with the three groups, which also provides the designation of the participants and the organisations that they belong to, to support the reliability and validity of this method.

\begin{tabular}{|l|l|l|}
\hline \multicolumn{2}{|l|}{ GROUP 1: PR Practitioners } & \multicolumn{2}{|l|}{} \\
\hline Companies / Agencies & Gender & Job Designation \\
\hline P1 & Male & Managing Director \\
\hline P2 & Female & Counselor and Senior Partner \\
\hline P3 & Female & Director, Corporate Affairs \\
\hline
\end{tabular}

\begin{tabular}{|l|l|l|}
\hline \multicolumn{2}{|l|}{ GROUP 2: Advertising Practitioners } & \multicolumn{2}{l|}{} \\
\hline Companies/Agencies & Gender & Designation \\
\hline A1 & Male & Group Advisor \\
\hline A2 & Male & Chief Executive Officer \\
\hline A3 & Female & Head, Marketing Communications \\
\hline GROUP 2: Netutral Practitioners & & \\
\hline Companies/Agencies & Gender & Designation \\
\hline N1 & Male & Chief Operating Officer \\
\hline N2 & Male & Editor, Supplement \\
\hline N3 & Male & Creative Director \\
\hline N4 & Female & Managing Editor \\
\hline
\end{tabular}

The sample above comprises of full time public relations and advertising practitioners who have been in practice for over 15 years. These practitioners are heads of corporate communications departments, heads of advertising departments as well as directors and senior partner of public relations and advertising agencies. Four other participants are selected to represent the neutral party and they comprise of a leader of a public listed company, creative director and media editors.

The study participants were asked for their views and explanations if editorial coverage and advertising perform differently on key measures of credibility and brand knowledge. They were also asked if the messaging in public relations does and should differ than the messaging in advertising, and under what condition the messaging/narrative should be crafted. They were also requested to provide 
their general perspectives on the adequacy of public relations and advertising in conveying the message to fulfill a company's objectives, as well as the present actual functions of public relations vis-a-vis advertising.

In addition, they also provided their take on the systems and procedures that have been established by companies with regard to public relations and advertising, and what their concerns were on the two communication tools.

Their perspectives on the effectiveness of public relations (editorial coverage/ publicity) and advertising to convey the intended message and/or address relevant issues/concerns were also obtained. Finally, they were asked for their views on the issues and concerns in connection with the functions of public relations and advertising, and the formal systems that have been in place to deal with these issues and concerns.

\section{FINDINGS}

\section{Credibility}

In general, the participants favored public relations in terms of credibility of the message. In terms of brand awareness and knowledge, the participant prefers advertising.

Public relations practitioners believe that because public relations enables more story or narrative to be told, and told by a third party, its message thus is more credible and trustworthy. Trust, to them, is earned, hence public relations' editorial coverage is the "earned media". The view is shared by the neutral participants who feel that the public relations message is more credible in the sense that the company does not pay to get it out and that it comes from another source other the company itself.

However, the views among advertising practitioners were divided, with two of the participants agree that the public relations message is more credible, while the other believes that because both public relations and advertising have different roles to play, they are credible in their own ways.

\section{Messaging}

There were mixed views among participants on whether the messages of public relations and advertising should differ. One of the participants believes that the messaging should be consistent for advertising and public relations, while the other feels that advertising, in contrast to public relations, is sales oriented and therefore the messaging uses hard-sell language.

Other participants feel that advertising is driven by public relations messages. On the other hand, the messaging of public relations and advertising does and should differ because of their different objectives. On the other hand, advertising is mainly to support the marketing and sales of a particular product, whereas public relations goes beyond that and looks at the bigger aspect of communications. The findings also revealed that the messaging can differ, depending on the intended objective. Public relations has a bigger role to play because it is directed to 
stakeholders and not only consumers of that product as with advertising.

\section{Condition}

A general observation was that the messaging or narrative should be crafted in neutral circumstances, where most of the participants agree that in a difficult situation or in time of crisis, public relations must take the lead. On another condition, at a time when the company wants to boost sales, advertising messages must lead.

\section{Adequacy}

All public relations practitioners who participated in this study believe that public relations is not yet sufficient and this is especially true for Malaysian companies. This is supported by the neutral participants who feel that in big companies such as multinationals, public relations is adequate. However, in smaller companies such as family-run businesses, public relations is deficient. In contrast, the data indicate that advertising is sufficient in conveying the message to fulfill the company's objectives.

\section{Balance}

The unanimous view was that there is no balance between advertising and public relations, with the former surpassing the latter. The study revealed that there must be a strategic approach because when they (public relations and advertising) overlap, their full potential may not be realised.

\section{Accreditation}

The general consensus was that advertising and public relations practitioners lack accreditation and this is particularly true for public relations practitioners. Because of this, public relations practitioners may not be taken seriously.

\section{Functions}

Four common themes derived from the perspective of the actual functions of public relations and advertising: Perception; Management Function; Existence; and Content and Substance.

Public relations are perceived as media relations when in fact, public relations must be about story-telling and the media is one of the avenues for the story to be told. Advertising, as the data indicates, is always about getting a premium space at the best cost. It was also found that the function of both public relations and advertising is to build corporate reputation, in their respective ways, and that both public relations and advertising function on contents and substance. However, unlike public relations, advertising has its main objective which is to drive sales. Therefore, advertising functions as a vital marketing tool while public relations build bridges between the company and stakeholders.

The findings of the study show that public relations and advertising do and must co-exist and work together because the functions of public relations and advertising are somehow inter-related.

\section{Systems and Procedures}


The findings also reveal that there has to be a strategic business plan or corporate plan from which public relations and advertising will be guided upon. Compared to public relations, advertising has more strategic direction mainly because the cost is more expensive.

\section{Concerns}

The main concern, as the study found, is the fragmentation of media, which refers to various media channels, namely the traditional media (broadcast, radio, print), the hybrid media (online newspaper), the social media (Facebook, Instagram, Pinterest, Twitter) and the owned media (own website, YouTube channel, blog). Such phenomenon means that public relations practitioners need to come out with an engaging story or narrative, as do advertising practitioners to select the most appropriate channels for the advertisements. It is therefore important for public relations and advertising practitioners to understand how the media comes together.

Another area of concern is that public relations and advertising professions must have qualified people to implement the tasks. Additionally, there is also a concern about measurement mechanism on the effectiveness of both public relations and advertising. Public relations have always been measured against the comparison of advertising value equivalent. For advertising, the concern was that there is not enough research done to leverage on the result and to get the optimum output.

\section{Effectiveness}

The participants in general believe that the effectiveness of public relations and advertising to convey the intended message and/or address relevant issues is based on two areas of content and skill.

As the study revealed, the message content must be interesting to ensure effectiveness. On this matter, public relations, being a third party endorsement, are more effective than advertising. However, to be effective, public relations must tell interesting, credible stories while advertising must have an "out-of-thebox" and creative message strategy. On the contrary, the effectiveness weighs more on advertising as it gives longer shelf life and creative control as compared to public relations. The data indicate that with the right content, public relations is more effective; and with the right channel, advertising is more effective.

The study also revealed that skill of the practitioners is very important to ensure effectiveness in conveying the message(s). Public relations practitioners must know how to craft a certain message, the timing, the relationship, the environment and the people to reach out to. Advertising takes truly creative people to craft ads to achieve its overall effectiveness.

\section{DISCUSSION}

The findings of this study highlight the co-relations of public relations and advertising in conveying the messages that are perceived as credible by the 
target audience. The data also enables comparison and determinant of the communications effectiveness of public relations and advertising, and finally, suggests if public relations and advertising do come together for the most efficient communications programme.

The findings tally with the Source Credibility Theory which states that people are more likely to be persuaded when the source presents itself as credible (Hovland et al., 1953). This theory is studied for practical applications in communications, to connect with and understand the reliability and trustworthiness impact of message on people or audience, and is particularly relevant to this study.

In examining and understanding the co-relations between public relations and advertising, particularly in conveying the messages that are perceived as credible by the target audience, a few themes and measures have emerged, including: credibility of message, brand knowledge, messaging, message objective, the condition under which message must be out and the channel in which message must be in.

Based on the data gathered, public relations messages are perceived by the participants to be more credible. To public relations practitioners, a message is about a narrative or a story, and the more interesting and compelling the story is, the more engaging it becomes. The findings of the study also indicate that public relations practitioners believe that it is important for a company or an organisation to connect with consumers and stakeholders through story telling. Storytelling has always been in the communication culture from the beginning of time. They consider that a powerful story creates resonance. Public relations enables this to happen - for a powerful narrative or story to be told - which will over time build relations and in turn, build trust. As Grunig (1992) argues, it is all about building good relationships with strategic publics.

\section{ABOUT THE AUTHORS}

Jamilah Haji Ahmad is an Associate Professor and the Dean at the School of Communication, Universiti Sains Malaysia (USM). Her area of interest include public relations, corporate social responsibility (csr), community relations \& communication, corporate communication, communication \& media studies, environmental communication, elearning, new media technology. She can be contacted at E-mail:jahmad@usm.my/dean_com@usm.my

Tengku Adrian Ismail is a graduate student at the School of Communication, Universiti Sains Malaysia. His area of interest includes audience research, media regulation, and media industries. 


\section{REFERENCES}

AAAA Malaysia. (2014). What is 4As?. Retrieved from http://www.aaaa.org. my/.

Abdullah, Z., \& Threadgold, T. (2008). Towards the professionalisation of public relations in Malaysia: Perception management and strategy development. Public Relations Review, 34 (3), 285-287.

Advertising.my (2014). Advertising in Malaysia- What's in store for 2014. Retrieved from http://e.advertising.com.my/marketing-tips-2014.

Asia Media (2014). About Asia Media. Retrieved from http://www.asiamedia. net.my/.

Bovee, C.L. and Arens, W.F. (1992), Contemporary Advertising, 4th ed., Richard P. Irwin Inc., Homewood, IL.

Cameron, G. T. (1994). Does publicity outperform advertising? An experimental test of the third-party endorsement. Journal of Public Relations Research, 6(3), 185-207.

Grunig, J. E. (1992). Communication, public relations, and effective organizations: An overview of the book. In J. E. Grunig (Ed.), Excellence in public relations and communication management (pp. 327-355). Hillsdale, NJ: Lawrence Erlbaum.

Grunig, J. E., \& Hunt, T. (1984). Managing public relations. New York: Holt, Rinehart \& Winston.

Hovland, C. I., Janis, I.L. \& Kelley, H.H. (1993). Communication and persuasion. New Haven: Yale University Press.

Hutton, J. (1999). The definition, dimensions, and domain of public relations. Public Relations Review, 25(2), 199-214.

Hutton, J. G., Goodman, M. B., Alexander, J. B., \& Genest, C. M. (2001). Reputation management: the new face of corporate public relations?. Public Relations Review, 27(3), 247-261.

Kirk, J., \& Miller, M. L. (1986). Reliability and validity in qualitative research. Beverly Hills: Sage Publications.

Kitchen, P. J. (1997). Public relations: Principles and practice. London: International Thomson Business Press.

Kotler, P. \& Mindak, W. (1978) Marketing and Public Relations. Journal of Marketing, 42 (4), 13-20.

Krathwohl, D. R. (1998). Methods of educational \& social science research: An integrated International Journal of Education approach (2nd ed.). White Plains, NY: Addison Wesley Longman, Inc.

L 'Etang, J. \& Pieczka, M. (1996). Critical perspectives in public relations. London. International Thompson Business Press.

L'Etang, J. (1999). Public relations education in Britain: an historical review in the context of professionalisation. Public Relations Review, 25(3), 261289.

L'Etang, J. (2003). Public relations education in Britain: A review at the outset 
of the millennium and thoughts for a different research agenda. Journal of Communication Management, 7(1), 43-53.

L'Etang, J. (2004). Public relations in Britain: A history of professional practice in the 20th century. London: Lawrence Erlbaum Associates.

Michaelson, D., \& Stacks, D. W. (2007). Exploring the comparative communications effectiveness of advertising and public relations: An experimental study of initial branding advantage. Institute for Public Relations, 3(3), 1-22.

Mohd Hamdan, A. (2010). Government and Political Public Relations: An Introduction. Selangor: UPENA, UiTM.

Patton, M. Q. (1990). Qualitative evaluation and research methods (2nd ed.). Newbury Park, CA: Sage Publications, Inc.

PRweb (2014). Free guide: 15 digital marketing tactics!. Retrieved from $\mathrm{http} / / /$ service.prweb.com/learning/article/15-digital-marketing-tactics/.

Sallot, L. M., Cameron, G. T., \& Lariscy, R. A. W. (1997). Professional standards in public relations: A survey of educators. Public Relations Review, 23(3), 197-216.

Sallot, L. M., Cameron, G. T., \& Weaver Lariscy, R. A. (1998). Pluralistic ignorance and professional standards: Underestimating professionalism of our peers in public relations. Public Relations Review, 24(1), 1-19.

Seidman, I. (1998). Interviewing as a qualitative research: A guide for researchers in education and the social sciences. (3rd Ed.) . New York: Teachers' College Press.

Silverman, D. (1985). Qualitative methodology and sociology. Aldershot (Hants.): Gower.

Stacks, D. W., Botan, C., \& Turk, J. V. (1999). Perceptions of public relations education. Public Relations Review, 25(1), 9-28.

Syed Arabi Idid (2004). Public relations in Malaysia from its colonial past to current practice in Sriramesh, K.(2004). Public Relations in Asia. Australia: Thomson Learning Pte Ltd.

UNICEF (2008, September 1). Malaysia code of advertising practice. Retrieved from http://www.unicef.org/malaysia/Code-of-AdvertisingPractice.pdf.

White, J and Mazur, L (1995). Strategic Communications Management, Addison- Wesleym Wokingham, UK: Universities Press. 